\title{
Reporting in the area of sustainable development with information technology application
}

\author{
Aygul Zufarovna Ibatova ${ }^{a^{*}}$, Farit Foatovich Sitdikov ${ }^{b}$ and Guzalija Salihovna Klychova ${ }^{c}$
}

${ }^{a}$ Industrial University of Tyumen, Russia

${ }^{b}$ Kazan Federal University, Kazan, 420008, Russia

${ }^{c}$ Kazan State Agrarian University Kazan, 420015, Russia

\section{H R O N I C L E}

Article history:

Received: January 11, 2018

Received in revised format:

March 3, 2018

Accepted: May 16, 2018

Available online:

May 16, 2018

Keywords:

Global reporting initiative

(GRI)

Sustainability reporting

Reporting guidelines

Information technologies

\author{
A B S T R A C T
}

The aim of the present article is substantiation of theoretical provisions and development of practical recommendations for reporting in the field of sustainable development formation in compliance with the international standard "Guidelines for sustainability reporting" elaborated within the scope of Global Reporting Initiative. The research objectives are to study the content of non-financial reporting generated in compliance with the Global Reporting Initiative (GRI) guidelines and to offer new methodological approaches towards sustainability reporting formation. Using such general scientific methods as systematic approach, comparison, method of systematization and generalization of data, the research work revealed the essence, content, principles of formation and reporting structure in the field of sustainable development. The work contains recommendations on social activity accounting organization with the use of information technology, such as: supplementary invoices application for accounting, and development of forms for reports containing information of social character.

\section{Introduction}

Non-financial reporting presentation is one of the tools to increase the investment attractiveness of an organization. It reflects the results of the company's activity in respect to its influence on the social and environmental spheres. Standards, among which we can accentuate the "Global Reporting Initiative" (hereinafter referred to as GRI), Standards and the Institute of Social and Ethical Accountability Standard (AccountAbility 1000, AA1000), have been developed in the area of non-financial reporting. The companies at present independently determine the content, forms and a system of non-financial reporting indicators. In this connection, it is necessary to develop and adopt a common structure of consolidated reporting on sustainability issues. Many companies prefer to generate non-financial reporting in accordance with the generally recognized international standard "Guidelines for Sustainability Reporting" developed under the Global Reporting Initiative. The application of the GRI Guidelines is a voluntary initiative in most of the countries (Stec et al., 2017; Grafé-Buckens \& Jankowska, 2001). Sustainability reporting is a complex information system reflecting the costs of sponsorship and charity programs of a

* Corresponding author.

E-mail address: aigoul@rambler.ru (A. Z. Ibatova)

(C) 2018 by the authors; licensee Growing Science, Canada doi: $10.5267 /$ j.msl.2018.5.008 
company, the costs of ecological and environmental protection measures which render impact on the company, shareholders, contractors and government bodies and the like development (Klychova et al., 2015). The Sustainability Reporting Guidelines provide for the possibility of reports generation in two versions: basic and expanded. The choice of the version does not depend on the location, size or industrial belonging of the organization. The selected variant should meet the needs of the company and the information needs of the parties concerned.

Information on economic, environmental and social impact of the organization is disclosed within the framework of significant aspects. The basic version of the reports preparation contains information subject to obligatory disclosure by the company, on the impact of its economic, environmental, social activity as well as the corporate governance activity. The extended version is built on a basic version, but requires the inclusion of additional standard reporting elements on strategy and analysis, corporate governance, as well as ethics and the company's bona fides.

The following principles shall be observed at the Sustainability Reporting development:

1. Determination of the report contents, which include: interaction with stakeholders, the sustainability development context, significance, completeness.

2. The quality of the report provision: balance identity, comparability, accuracy, timeliness, clarity, reliability.

In accordance with the report content determination principles, the reporting organization shall disclose information:

- on the degree of employees, shareholders, suppliers interests consideration, as well as the vulnerable local population groups, social groups, and others;

- on the organization performance in the broad context of sustainable development;

- reflecting the significant impact of the organization on the economy, the environment and the society.

The information in the reporting shall be sufficient to reflect a significant impact on the economy, the environment and the society and give the stakeholders the opportunity to assess the performance of the organization for the reporting period (Alonso-Almeida et al., 2014; González et al., 2015).

The report quality provision principles regulate the issues of proper presentation of information in the sustainability reporting. The report reflects positive and negative aspects of the company's performance in accordance with these principles. Information shall be presented to allow the stakeholders to analyze the changes in the company's performance. Stakeholders using the report shall be able to compare the information provided on the economic, environmental and social performance of the company with the results of the company's activity for the previous periods and its objectives and, as far as possible, with the performance of other companies (Fuente et al., 2017; Klychova et al., 2016). Reporting is provided at regular intervals, and is published in a form that is understandable and accessible to the parties concerned. Stakeholders shall be sure of the possibility to verify the report for proving the reliability degree of its content and the adequacy of the reporting principles application (Needles Jr. et al., 2016).

The accounting data is a key source of information in the process of indicators formation for the sustainable reporting. Social activity accounting is a set of activities aimed at generating a report based on information from primary accounting (Klychova et al., 2015; Klychova et al., 2017). The most effective way of providing accounting data is automation of accounting processes through the use of information technology (Klychova \& Yusupova, 2017). Information technology shall be understood as the process of storage, processing, transmission, protection and display of information, focused on increasing the activity efficiency. When organizing an automated sustainable reporting system, it is necessary to take into account the fact that the data is provided by the accounting department of the enterprise. Therefore, 
they determine the composition of the primary documents that will be used to compile the reports (Klychova et al., 2014). They also reveal the relationships between the indicators of all reporting forms and develop a workflow scheme used in planning (Klychova et al., 2015).

The GRI standard adopted in 2016 consists of 36 modules: 3 universal and 33 specialized, dealing with specific aspects of the organization. Specific standard elements of reporting are grouped into three categories: economic, environmental and social. Undoubtedly, the main factor in the operation efficiency of any company is the knowledge of the needs of its main customers. Key success factors are understood as follows: a high level of production, high quality products, qualified personnel, an optimal program for products promotion and manufacturing new products complying with market requirements (Letsoalo et al., 2014).

\section{Methodology}

During the research we used some general scientific and logical methods, including: analysis, synthesis, abstraction, and modeling.

The problem of the Global Reporting Initiative (GRI) was investigated by some scientists from different points of view. In terms of macro and microanalysis, the Global Reporting Initiative (GRI) was presented in 2012 (Marimon et al., 2012). Instability and concentration as two indicators of GRI distribution in different sectors of activity were analyzed by these scientists. The evaluation of the quality and inclusiveness of triple reports based on the non-financial reporting system and guidelines is presented in the analysis of non-financial reporting at the country level (Skouloudis, et al., 2010). The Global Reporting Initiative as the basis for voluntary reporting of companies in the field of sustainable development is used to analyze discursive, material and charismatic types of tactics (Brown et al., 2009). At the same time, GRI as the basis for voluntary reporting was used in corporate environmental and social spheres. The authors argue that institutional theory should pay more attention to strategies and resources; institutional entrepreneurship, is constrained by the structural strength of broader institutions and trade-offs; NGO strategies can change the scope of corporate governance (Levy et al., 2010). GRI will be an effective complement to interviews, press releases, media reports used in making investment decisions (Willis, 2003). Troppinen et al. (2013) explored the Global Reporting Initiative (GRI) through philanthropy, the creation of prosperity, communication and the social impact of core activities. In order to mitigate and avoid inadequate verification of reporting, large forest companies announced the voluntary adoption of guidelines for a global initiative in reporting (GRI) (Troppinen et al., 2012). Another learning tool The GRI Global Reporting Initiative was used (the Triple Bottom Line) by Stenzel (2010). Many management regimes have been studied in accordance with the Global Reporting Initiative (GRI). One such regime is the transnational management (Barkemeyer et al., 2015).

\section{Results}

The category of "Ecological" considers a degree of environmental impact rendered by the company and measures a negative impact on nature. Information is disclosed in several aspects: materials, energy, water, biodiversity, emissions, discharges and wastes, products and services. The aspect "Materials" requires indication of the total amount or volume of materials expended in the production and packaging of the main products and services in the company during the reporting period, broken down by the consumed non-renewable and renewable materials. Renewable materials include materials produced from renewable resources, that is, resources having the capacity for self-renewal, which can last for a certain period of time (biosphere - plant and animal life). One of the most effective ways to solve the problem of recycling wood wastes (Toppinen et al., 2012; Toppinen \& Korhonen-Kurki, 2013) is their recycling into fuel briquettes. Non-renewable resources include minerals, which have found wide applications in modern industry being a raw material for fuel production (stone and brown coal, slate, peat, oil) and building materials. We propose to specify the sub-account "Renewable materials" and "Non-renewable materials" in the account "Materials" in the computer plan of all accounts (Table 1). 
Table 1

Excerpt from the Plan of Accounts: accounts of materials

\begin{tabular}{|c|c|c|c|c|}
\hline $\begin{array}{l}\text { Plan of account } \\
\text { Account code }\end{array}$ & Account name & Sub-count & Type* & Quan* \\
\hline 10 & Materials & Nomenclature & $\mathrm{A}$ & + \\
\hline 10.01 & Renewable materials & Nomenclature & A & + \\
\hline 10.01 .1 & Raw and materials & Nomenclature & A & + \\
\hline 10.01 .2 & Fuel & Nomenclature & $\mathrm{A}$ & + \\
\hline 10.01 .3 & Tare and tare materials & Nomenclature & A & + \\
\hline 10.01 .4 & Spare parts & Nomenclature & A & + \\
\hline 10.01 .5 & Building materials & Nomenclature & $\mathrm{A}$ & + \\
\hline 10.02 & Non-renewable materials & Nomenclature & A & + \\
\hline 10.02 .1 & Raw and materials & Nomenclature & A & + \\
\hline 10.02 .2 & Fuel & Nomenclature & A & + \\
\hline 10.02 .3 & Tare and tare materials & Nomenclature & A & + \\
\hline 10.02 .4 & Spare parts & Nomenclature & A & + \\
\hline 10.02 .5 & Building materials & Nomenclature & A & + \\
\hline
\end{tabular}

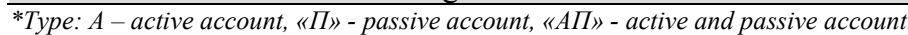

*Quan.: indicator of quantitative calculation in the account.

Operations on receipt and disposal are recorded in documents on materials acquisition, sale and writingoff into production. Primary documents are a source of information for the automated filling in of reports providing non-financial information (McElhaney 2009, Safiullin et al., 2014). For sustainable reporting in the aspect of "Materials" we propose to use the form of a turnover-balance sheet, which is incorporated in any computer accounting program, making a certain additions into the details of the report (Table 2).

Table 2

Nonfinancial reporting form "Report: aspect "Materials"

\begin{tabular}{|c|c|c|c|c|c|c|c|}
\hline \multirow[t]{2}{*}{ Nomenclature } & \multirow[t]{2}{*}{ Indicators } & \multicolumn{2}{|c|}{ Opening balance } & \multicolumn{2}{|c|}{ Period turnover } & \multicolumn{2}{|c|}{ Closing balance } \\
\hline & & Debit & Credit & Debit & Credit & Debit & Credit \\
\hline Renewable & $\mathrm{ACC}$ & 309800.00 & & 4000.00 & 81850.00 & 231950.00 & \\
\hline \multirow[t]{2}{*}{ Fuel brick } & $\mathrm{ACC}$ & 301800.00 & & & 75450.00 & 226350.00 & \\
\hline & Quan. & 50300.00 & & & 12575.00 & 37725.00 & \\
\hline \multirow[t]{2}{*}{ Timber } & $\mathrm{ACC}$ & 8000.00 & & 4000.00 & 6400.00 & 5600.00 & \\
\hline & Quan. & 1000.00 & & 500.00 & 800.00 & 700.00 & \\
\hline Non-renewable & $\mathrm{ACC}$ & 1000.00 & & 200.00 & 780.00 & 420.00 & \\
\hline \multirow[t]{2}{*}{ Petrochemicals } & $\mathrm{ACC}$ & 400.00 & & 200.00 & 480.00 & 120.00 & \\
\hline & Quan. & 10000.00 & & 5000.00 & 12000.00 & 3000.00 & \\
\hline \multirow[t]{2}{*}{ Building sand } & $\mathrm{ACC}$ & 600.00 & & & 300.00 & 300.00 & \\
\hline & Quan. & 2000.00 & & & 1000.00 & 1000.00 & \\
\hline Total & $\mathrm{ACC}$ & 310800.00 & & 4200.00 & 82630.00 & 232370.00 & \\
\hline
\end{tabular}

We propose to specify the following data in the computer plan of accounts, particularly in the account of costs for auxiliary production of the sub-account by types of sources and directions of energy consumption, for reflecting of information within the framework of the "Energy" aspect (Table 3).

Table 3

Excerpt from the Plan of Accounts: accounts of costs for electric energy

\begin{tabular}{|c|c|c|c|c|}
\hline Account code & Account name & Sub-count & Type & Quan. \\
\hline 23 & Auxiliary production & Cost item & $\overline{\mathrm{A}}$ & + \\
\hline 23.1 & Energy consumption of non-renewable sauces & Cost item & A & + \\
\hline 23.1 .1 & Electric energy for heating consumption & Cost item & A & + \\
\hline 23.1 .2 & Electric energy for cooling consumption & Cost item & A & + \\
\hline 23.1 .3 & Steam consumption & Cost item & A & + \\
\hline 23.2 & Power from renewable sources consumption & Cost item & A & + \\
\hline 23.2 .1 & Electric energy for heating consumption & Cost item & A & + \\
\hline 23.2 .2 & Electric energy for cooling consumption & Cost item & A & + \\
\hline 23.2 .3 & Steam consumption & Cost item & A & + \\
\hline
\end{tabular}


In computer accounting, the receipt and consumption of electricity is registered in the Act of rendered services. We propose a form of the report with the indicator "renewable" ("non-renewable") included in the settings to summarize the data in the aspect of "Energy" (Table 4).

Table 4

Nonfinancial reporting form "Report: aspect "Energy"

\begin{tabular}{clcc}
\hline Consumption direction & Indicators & \multicolumn{2}{c}{ Consumption for the period } \\
\hline Non-renewable & ACC & 400000.00 & 400000.00 \\
\hline heating & ACC & 200000.00 & 200000.00 \\
& Quan. & 50000.00 & 50000.00 \\
\hline \multirow{2}{*}{ cooling } & ACC & 80000.00 & 80000.00 \\
& Quan. & 20000.00 & 20000.00 \\
\hline steam & ACC & 120000.00 & 120000.00 \\
& Quan. & 30000.00 & 30000.00 \\
\hline Total & ACC & $\mathbf{4 0 0 0 0 0 . 0 0}$ & $\mathbf{4 0 0 0 0 0 . 0 0}$ \\
\hline
\end{tabular}

Water supply of organizations (especially industrial and agricultural enterprises), and its disposal shall represent a unified system, in which all processes occur stepwise as follows: water supply, its disposal and treatment before re-use. Sewage waters, which are formed as a result of economic activity, may appear environmental threat. Organization of in-plant recycling zero discharge water supply system at the enterprise shall be one of the methods to eliminate such type of threat. For industrial purposes, it is advisable to use water not from drinking water pipe, particularly from a utility water supply network, but from wastewater source recovered for the secondary use. Water recycling gives economic benefit to an enterprise from its secondary use, and also reduces the negative impact on water bodies (Ahmad et al., 2017). To obtain data on the water volume consumption, it is possible to specify it in the account for auxiliary production costs of the sub-account for water supply sources (Table 5).

Table 5

Excerpt from the Plan of Accounts: accounts of costs for water supply

\begin{tabular}{lllll}
\hline Account code & Account name & Sub-count & Type & Quan. \\
\hline 23 & Auxiliary production & Cost item & A & + \\
23.3 & Water supply & Cost item & A & + \\
23.3 .1 & Surface waters (including bogs, rivers, lakes and oceans) & Cost item & A & + \\
23.3 .2 & Underground waters & Cost item & A & + \\
23.3 .3 & Rain waters, collected and stored by the company & Cost item & A & + \\
23.3 .4 & Sewage waters of the other organization & Cost item & A & + \\
23.3 .5 & Municipal and other water supply systems & Cost item & A & + \\
\hline
\end{tabular}

In computer accounting, water supply is registered in the Act of rendered services. For the sustainable reporting in the aspect of "Water" we can use the data of the turnover-balance sheet for the accounting of auxiliary production. Industrial and agricultural enterprises render impact on all environmental components: flora and fauna, air, water. Gases, wastewater, industrial wastes are emitted into the atmosphere and reservoirs. Wastes are divided into the utilizable and non-utilizable. Utilizable wastes can be re-used as fuel, feed and fertilizers, as well as raw materials for production, both at the enterprise itself and for realization to other enterprises. The re-used discharges volume of another organization shall be specified in non-financial reporting. A separate sub-account on the settlement account with different debtors and creditors is proposed for their accounting (Table 6).

Table 6

Excerpt from the Plan of Accounts: accounts of wastes and discharges sold to the other company

\begin{tabular}{llcl}
\hline Account code & Account name & Sub-count & Type \\
\hline 76 & Settlements with different debtors and creditors & Contractors & AP \\
76.10 & Wastes and discharges sold to the other company & Contractors & AP \\
\hline
\end{tabular}


The total number of fines and non-financial sanctions imposed for non-compliance with environmental legislation, indicating the total amount of fines and the number of cases of non-financial sanctions, is specified in the sustainability reporting part of the "Compliance" aspect. If in the preparation of nonfinancial reporting no cases of environmental legislation violation have been revealed, a brief statement of this fact is made in the relevant section of "Compliance". In order to take into account the amount of the fine for non-compliance with regulatory requirements in the field of ecology, it is suggested to specify a sub-account of accounting account for other revenues and expenses (Table 7).

Table 7

Excerpt from the Plan of Accounts: accounting of fines for non-compliance with regulatory requirements

\begin{tabular}{llll}
\hline Account code & Account name & Sub-count & Type \\
\hline 91 & Other revenues and expenses & Other revenues and expenses & AP \\
91.01 & Other revenues and expenses & Other revenues and expenses & P \\
91.02 & Other revenues and expenses & Other revenues and expenses & A \\
91.02 .1 & $\begin{array}{l}\text { Fines for non-compliance with environmental legislation } \\
\text { and regulatory requirements }\end{array}$ & Other revenues and expenses & A \\
& & & \\
\hline
\end{tabular}

The "General Information" aspect requires reflecting the costs of environmental protection, including the costs for:

1) storage or utilization of wastes and purification of emissions;

2) liquidation of environmental damage;

3) for prevention of the environmental impact and for the system of environmental management.

The following special fixed assets are provided for the environmental protection from the negative impact rendered by the activity of enterprises:

- control and measuring equipment for determining the volume of emissions into the atmosphere, discharge and concentrations of pollutants;

- facilities and installations for wastewater treatment;

- facilities for waste disposal (polygons, storage tanks);

- installations for trapping and neutralizing harmful substances from gases coming from process units and from ventilation air, just before they are released into the atmosphere;

- equipment for collection of oil, garbage and other wastes from the water basins of rivers and water reservoirs;

- equipment, vehicles and communication facilities designed for the operation of natural reserves and other nature conservation areas;

- equipment for noise and vibration level reduction from industrial installations, transport;

- equipment for processing, neutralization and disposal of radioactive wastes.

The costs due to acquisition and construction of fixed assets for nature protection purposes shall be considered in a separate sub-account "Construction and acquisition of fixed assets intended for nature protection purposes" to the account "Investments in non-current assets" (Klychova et al., 2015; Klychova et al., 2017) (Table 8).

Table 8

Excerpt from the Plan of Accounts: accounting of fixed assets intended for nature protection purposes

\begin{tabular}{llll}
\hline Account code & Account name & Sub-count & Type \\
\hline 08 & Investments in non-current assets & & A \\
08.09 & Fixed assets of nature protection purposes & Nomenclature & A \\
\hline
\end{tabular}

Current costs associated with the maintenance and operation of inventory, fixed assets of environmental and nature protection purposes, which are used for air, water basins purification, noise, vibrations and 
harmful emissions elimination, must be accounted for separately (Fakhretdinova et al., 2015). To account for these expenses, we recommend opening additional accounts to the working plan of the economic entity accounts. For example, you can open an account "Costs for the maintenance of inventory and fixed assets intended for nature protection purposes". This account can correspond to the accounts of expenses calculation, which are meant for writing-off the costs associated with the operation and maintenance of fixed assets and inventory intended for nature protection and environmental purposes (Klychova et al., 2015) (Table 9).

\section{Table 9}

Excerpt from the Plan of Accounts: accounting of costs for inventory maintenance and fixed assets intended for nature protection purposes

\begin{tabular}{ll}
\hline Account code & Account name \\
\hline 17 & $\begin{array}{l}\text { Costs for operation and maintenance of fixed assets and inventory intended for nature protection } \\
\text { purposes }\end{array}$ \\
\hline
\end{tabular}

To account for the costs of accepting, storage or disposal of ecologically hazardous wastes, it is recommended to use the free account "Expenses for acceptance, storage and disposal of hazardous wastes" by the wastes management directions (Table 10).

\section{Table 10}

Excerpt from the Plan of Accounts: accounting of costs for acceptance, storage and disposal of hazardous wastes

\begin{tabular}{ll}
\hline Account code & Account name \\
\hline 18 & Expenses for acceptance, storage and disposal of hazardous wastes \\
\hline
\end{tabular}

It is supposed to compile the report Based on the information received from the account "Costs for acceptance, storage, disposal of hazardous wastes" in the form proposed in Table 11.

\section{Table 11}

Non-financial accounting form "Report: Costs for acceptance, storage and disposal of hazardous wastes"

\begin{tabular}{ll}
\hline Reference directions & Period from 01.10 .2017 to 31.12 .2017 \\
\cline { 1 - 2 } secondary use & 5000.00 \\
multiple use & 2000.00 \\
composting & 3000.00 \\
burning down in bulk & 21200.00 \\
pumping into deep underground horizons & 1200.00 \\
storage on the polygon & 20000.00 \\
storage on the enterprise site & 20000.00 \\
\hline Total & $\mathbf{7 2 4 0 0 . 0 0}$ \\
\hline
\end{tabular}

"Lesnoy Rodnik" LLC

Report: Costs for acceptance, storage and disposal of hazardous wastes

Period: 4 quarter, 2017.

Account: 18

In social reporting, the following data shall be reflected: expenses on the protection of flora and fauna; on protection of architectural monuments, historical sites and ancient settlements, representing scientific, cultural and public interest; preservation of natural landscapes. For accounting of these costs, we can apply the free account "Costs for nature protection events" by opening the corresponding sub-accounts (Table 12).

Research activities for reduction of negative impacts on the environment involve the development of new ways and tools for protecting the environment. The costs of biodiversity protection include the costs of habitat conservation, protection and restoration of species numbers, as well as laboratory research and analytical measurements. Protection of water reservoir consists in organization of a water supply system, including the purification of sewage and cooling water, as well as in the constant monitoring and laboratory analysis of water quality. 
Table 12

Excerpt from the Plan of Accounts: accounting of costs for nature protection events

\begin{tabular}{ll}
\hline Account code & Account name \\
\hline 27 & Costs for nature protection events \\
27.1 & Scientific-research activity for negative impact on the environment decrease \\
27.2 & Bio-diversity protection \\
27.3 & Water reservoir protection \\
27.4 & Air basin protection \\
27.5 & Protection from noise, vibration, hazardous radiation \\
27.6 & Energy saving activities \\
27.6 .1 & Electric energy saving \\
27.6 .2 & Water saving \\
\hline 27.6 .3 & Fuel saving \\
\hline
\end{tabular}

Measures of the air basin protection include purification of ventilation gases and laboratory studies of atmospheric air. Protection from noise, vibration, harmful radiation is achieved through the use of antinoise and anti-vibration facilities for transport, and environmental safety provision during transportation and processing of highly radioactive wastes. Based on the data generated by the documents on the writing-off of materials for the nature protection events implementation (request-waybill), calculation of wages, accrual of depreciation, etc., a report is expected to be drawn up (Table 13).

\section{Table 13}

Nonfinancial accounting form "Report: Costs for nature protection events implementation"

\begin{tabular}{ll}
\hline Type of events & Period from 01.10.2017 to31.12.2017 \\
\hline Scientific-research activity for negative impact on the environment decrease & 30000.00 \\
Bio-diversity protection & 10000.00 \\
Water reservoir protection & 20000.00 \\
Air basin protection & 10900.00 \\
Protection from noise, vibration, hazardous radiation & 900.00 \\
Electric energy saving & 10000.00 \\
Water saving & 10000.00 \\
Fuel saving & 30000.00 \\
\hline Total & $\mathbf{1 2 1 8 0 0 . 0 0}$ \\
\hline
\end{tabular}

"Lesnoy Rodnik" LLC

Report: Costs for nature protection events implementation

Period: 4 quarter, 2017.

Account: 27

In the "Social" category of sustainable reporting, the issues of staff-management relations, workplace safety, additional training and education of employees, non-discrimination, forced or compulsory labor, participation in the development of local communities shall be disclosed (Klychova et al., 2015). The content of subcategories of the Social section is regulated by international universal standards: the Universal Declaration on Human Rights, 1948; The International Convention on Economic, Social and Cultural Rights, 1966; The UN Convention on the Elimination of All Forms of Discrimination against Women, 1979; The International Labor Organization (ILO) Declaration on Fundamental Principles and Rights at Work (1998), which is based on eight ILO Conventions (on Forced or Compulsory Labor, on Freedom of Association and Protection of the Rights to Organization, on the Right to Organize and Maintain collective bargaining, equal remuneration, the abolition of forced or compulsory labor, discrimination in employment, the minimum age for admission to employment, the worst forms of child labor) (Consolidated set of GRI sustainability reporting standards, 2016). We can apply a free account 30 "Social Expenses" by opening the corresponding sub-accounts for accounting of expenses on ensuring a favorable life and work conditions of employees, allowances for pensions and benefits to retiring veterans of labor, medical treatment or rest repayment, holding classes in clubs, sports clubs and groups, attending cultural and entertainment or sports events, contributions to social programs of a sponsorship and charitable nature. Based on the results of these sub-accounts, it is proposed to use the form of the non-financial report "Social Expenses" (Table 14). 
Table 14

Form of non-financial reporting "Report: Expenses for nature protection events implementation"

\begin{tabular}{lc}
\hline Directions & Period from 01.10 .2017 to 31.12 .2017 \\
\hline Training and qualification upgrading & 5000.00 \\
Liability insurance & 2000.00 \\
Safe labor conditions provision & 3000.00 \\
Therapeutic resort treatment organization & 25800.00 \\
Benefits rendered to the employees, working on a full-time basis & 2800.00 \\
Benefits rendered to the young employees & 23000.00 \\
Benefits rendered to the pensioners and veterans & 2000.00 \\
\hline Total & $\mathbf{6 3 6 0 0 . 0 0}$ \\
\hline
\end{tabular}

"Lesnoy Rodnik" LLC

Report: Social Expenses

Period: 4 quarter 2017

Account: 27

As a result of non-financial reporting content study compiled in accordance with the guidelines of the Global Reporting Initiative, new recommendations have been proposed for the sustainable reporting development with the help of tools incorporated in the computer accounting program.

\section{Conclusions}

In this paper, the sustainable reporting has been formed on the basis of accounting data. There is a concern of the authorized organizations about a question of the primary documentation development for registration of operations connected with social activity of the enterprises. Application of information technology for the sustainable reports preparation will significantly simplify the process of obtaining the accounting data related to economic, environmental and social activity of the organization. Further work is needed to determine the composition and structure of reporting containing information of a social nature, as well as research on the methodology, which could serve the basis for resolving the issue of the relationship between the main forms of reports. The accounting methodology shall be directed to the social activity of the enterprise. Currently, many enterprises support this direction, which positively affects their business reputation.

\section{References}

Ahmad, N. K. W., de Brito, M. P., Rezaei, J., \& Tavasszy, L. A. (2017). An integrative framework for sustainable supply chain management practices in the oil and gas industry. Journal of Environmental Planning and Management, 60(4), 577-601.

Alonso-Almeida, M., Llach, J., \& Marimon, F. (2014). A closer look at the 'Global Reporting Initiative' sustainability reporting as a tool to implement environmental and social policies: A worldwide sector analysis. Corporate Social Responsibility and Environmental Management, 21(6), 318-335.

Barkemeyer, R., Preuss, L., \& Lee, L. (2015). On the effectiveness of private transnational governance regimes-Evaluating corporate sustainability reporting according to the Global Reporting Initiative. Journal of World Business, 50(2), 312-325.

Brown, H. S., De Jong, M., \& Lessidrenska, T. (2009). The rise of the Global Reporting Initiative: a case of institutional entrepreneurship. Environmental Politics, 18(2), 182-200.

Fakhretdinova, E.N., Klychova, G.S., Klychova, A.S., \& Antonova N.V. (2015). Development of accounting and financial reporting for small and medium-sized businesses in accordance with international financial reporting standards. Asian Social Science. 11(11), 318-322.

Fuente, J. A., García-Sánchez, I. M., \& Lozano, M. B. (2017). The role of the board of directors in the adoption of GRI guidelines for the disclosure of CSR information. Journal of Cleaner Production, $141,737-750$.

Global Reporting Initiative. (2016). Consolidated set of GRI sustainability reporting standards.

González, M., del Mar Alonso-Almeida, M., Avila, C., \& Dominguez, D. (2015). Modeling sustainability report scoring sequences using an attractor network. Neurocomputing, 168, 1181-1187. 
Grafé-Buckens, A., \& Jankowska, B. (2001). Toward a common framework for corporate sustainability reporting. Journal of Environmental Assessment Policy and Management, 3(1), 123-165.

Klychova, G.S., Zakirova, A.R., Zakirov Z.R., \& Iskhakov, A.T. (2014). Development of primary accounting of crop farming products arrival. Bulletin of Kazan State Agrarian University, 34(4), 23-28.

Klychova, G.S., Zakirova, A.R., \& Kamilova, E.R. (2015). Social initiatives accounting development in agricultural organizations. Kazan SAU Bulletin, 35(1), 25.

Klychova, G.S., Zakirova, A.R., \& Kamilova, E.R. (2016). The Methodological instruments of social audit in the agricultural companies development. International Business Management, 10, 5254-5260.

Klychova G.S., Ziganshin B.G., Zakirova A.R., Valieva G.R. and Klychova A.S., (2017). Benchmarking as an efficient tool of social audit development. Journal of Engineering and Applied Sciences, 12, 4958-4965.

Letsoalo, B., Coetzee, J., \& Ukpere, W. (2014). Stakeholders' Perceptions of a Human Resources Development Intervention. Mediterranean Journal of Social Sciences, 5(1), 740.

Levy, D. L., Szejnwald Brown, H., \& De Jong, M. (2010). The contested politics of corporate governance: The case of the global reporting initiative. Business \& Society, 49(1), 88-115.

Marimon, F., del Mar Alonso-Almeida, M., del Pilar Rodríguez, M., \& Alejandro, K. A. C. (2012). The worldwide diffusion of the global reporting initiative: what is the point?. Journal of Cleaner Production, 33, 132-144.

McElhaney, K. (2009). A strategic approach to corporate social responsibility. Leader to Leader, 52(1), 30-36.

Needles Jr, B. E., Frigo, M. L., Powers, M., \& Shigaev, A. (2016). Integrated reporting and sustainability reporting: An exploratory study of high performance companies. In Performance Measurement and Management Control: Contemporary Issues (pp. 41-81). Emerald Group Publishing Limited.

Skouloudis, A., Evangelinos, K., \& Kourmousis, F. (2010). Assessing non-financial reports according to the Global Reporting Initiative guidelines: evidence from Greece. Journal of Cleaner Production, 18(5), 426-438.

Stec, S., Paszkiewicz, M., \& Antypas, A. (2017). Is the time ripe for global binding norms for corporate accountability?. International Journal of Innovation and Sustainable Development, 11(2-3), 130-148.

Stenzel, P. L. (2010). Sustainability, the triple bottom line, and the global reporting initiative. Global Edge business review, 4(6), 1-2.

Toppinen, A., Li, N., Tuppura, A., \& Xiong, Y. (2012). Corporate responsibility and strategic groups in the forest-based industry: Exploratory analysis based on the Global Reporting Initiative (GRI) framework. Corporate Social Responsibility and Environmental Management, 19(4), 191-205.

Toppinen, A., \& Korhonen-Kurki, K. (2013). Global Reporting Initiative and social impact in managing corporate responsibility: a case study of three multinationals in the forest industry. Business ethics: A European review, 22(2), 202-217.

Willis, A. (2003). The role of the global reporting initiative's sustainability reporting guidelines in the social screening of investments. Journal of Business Ethics, 43(3), 233-237.

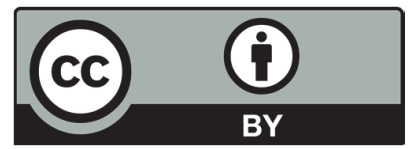

(C) 2018 by the authors; licensee Growing Science, Canada. This is an open access article distributed under the terms and conditions of the Creative Commons Attribution (CCBY) license (http://creativecommons.org/licenses/by/4.0/). 